\title{
islam nugantana
}

\section{Journal for Study of Islamic History and Culture}

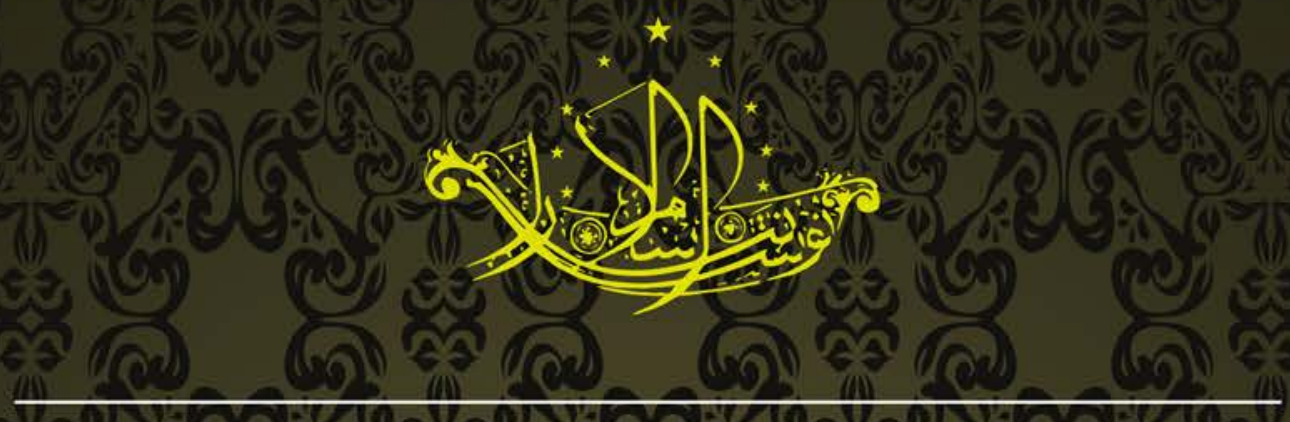

Pengantar Nomor Perdana - Nahdlatul Islam Nusantara Ahmad Suaedy

Anatomy of the Islam Nusantara Program and the Necessity for a "Critical" Islam Nusantarastudy

Okamoto Masaaki:

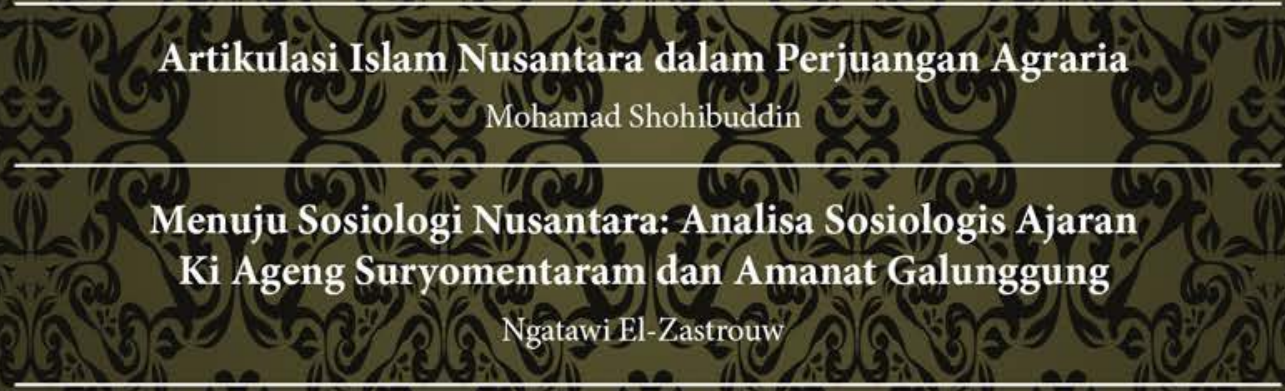

Traditional Islam and Global Religious Connectivity: Nahdlatul UTama in The Netherlands

Amin Mudzakkir

Lasem: Harmoni dan Kontestasi Masyarakat Bineka Syamsul Hadi

Traces of Māturidism in the 'Ulamā's Works in Nusantara in the Seventeenth Until Nineteenth Centuries

Muhamad Bindaniji

\section{Book Review}

Islam Dibawa Masuk oleh Orang Nusantara: Dari Data Terserak

Buzurgh Al-Ramahurmuzi, 'Ajaibul Hind: Kisah-Kisah Ajaib di Daratan dan Lautan Hindi

Idris Masudi 





Journal for Study of Islamic History and Culture

Pengantar Nomor Perdana - Nahdlatul Islam Nusantara

Ahmad Suaedy

Anatomy of the Islam Nusantara Program and the Necessity for a

“Critical” Islam Nusantara Study

Okamoto Masaaki

Artikulasi Islam Nusantara dalam Perjuangan Agraria

Mohamad Shohibuddin

Menuju Sosiologi Nusantara: Analisa Sosiologis Ajaran

Ki Ageng Suryomentaram dan Amanat Galunggung

Ngatawi El-Zastrouw

Traditional Islam and Global Religious Connectivity:

Nahdlatul Ulama in The Netherlands

Amin Mudzakkir

Lasem: Harmoni dan Kontestasi Masyarakat Bineka

Syamsul Hadi

Traces of Māturīdīsm in the 'Ulamā's Works in Nusantara in the Seventeenth Until Nineteenth Centuries

Muhamad Bindaniji

Book Review

Islam Dibawa Masuk oleh Orang Nusantara: Dari Data Terserak

Buzurgh Al-Ramahurmuzi, 'Ajaibul Hind: Kisah-Kisah Ajaib

di Daratan dan Lautan Hindi

Idris Masudi 


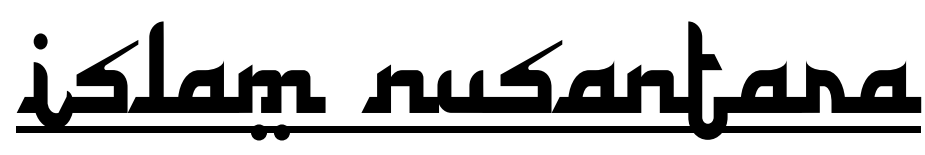

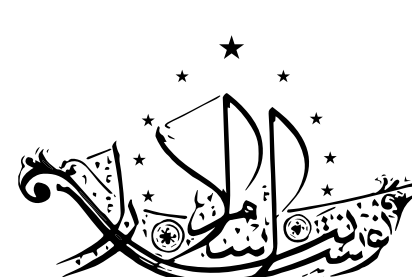




\section{islam rusantane}

Journal for Study of Islamic History and Culture

Volume I, Number I, July 2020

\section{EDITOR-IN-CHIEF}

Ahmad Suaedy, (Scopus ID: 56419869500) Faculty of Islam Nusantara UNUSIA Jakarta

\section{MANAGING EDITOR}

Ngatawi El-Zastrow, Faculty of Islam Nusantara UNUSIA Jakarta

INTERNATIONAL EDITORIAL BOARD

Said Aqil Siradj, Faculty of Islam Nusantara UNUSIA Jakarta

Robert W. Hefner, (Scopus ID: 36856758800) Boston University, Boston USA

Okamoto Masaaki, (Scopus ID: 57191206120), Kyoto University, Kyoto Japan

Dien Madjid, Universitas Islam Negeri Syarif Hidayatullah, Jakarta

Endang Turmudzi, Lembaga Ilmu Pengetahuan Indonesia (LIPI)

Alwi A. Shihab, Indonesian Muslim Intellectual and expert on Middle East Studies and Muslim Civilization

James Bourk Hoesterey, Emory University, Atlanta GA, USA

Hisanori Kato, (Scopus ID: 55996362300), Chuo University, Tokyo Japan

Abdul Moqsith, Universitas Islam Negeri Syarif Hidayatullah, Jakarta

Sahiron Syamsuddin, (Scopus ID: 55996362300) Universitas Islam Negeri Sunan Kalijaga,

Yogyakarta

Muhammad Ishom, Universitas Islam Negeri Sultan Maulana Hasanuddin, Banten

Azhar Ibrahim, (Scopus ID: 7202979037) National University of Singapore, Singapore

\section{ADVISORY EDITORS}

Hamdani, Faculty of Islam Nusantara UNUSIA Jakarta

\section{EDITORIAL BOARD}

Maria Ulfah, Faculty of Islam Nusantara UNUSIA Jakarta

Ulil Abshar Abdalla, Faculty of Islam Nusantara UNUSIA Jakarta

Syamsul Hadi, Faculty of Islam Nusantara UNUSIA Jakarta

Ali Abdillah, Faculty of Islam Nusantara UNUSIA Jakarta

Ayatullah, Faculty of Islam Nusantara UNUSIA Jakarta

Ulil Abshar, Universitas Islam Negeri Syarif Hidayatullah, Jakarta

Ahmad Ginandjar Sya'ban, Faculty of Islam Nusantara UNUSIA Jakarta

Idris Masudi, Faculty of Islam Nusantara UNUSIA Jakarta 
ISLAM NUSANTARA: Journal for Study of Islamic History and Culture facilitates the publication of article and book review on study of Islam, Muslim culture, social, politics and history in Southeast Asia (Nusantara) and beyond. It is published twice a year and written in Indonesia, English and Arabic. It aims to present academic insight of social and cultural complexity of Muslim world in Southeast Asia under the frame of dialectic between Islam and local culture or cultural realities.

The journal invites scholars and experts working in various disciplines in Islamic studies, humanities, and social sciences. Articles should be original, researchbased, unpublished and not under review for possible publication in other journals. All submitted papers are subject to a review of the editors, editorial board, and blind reviewers.

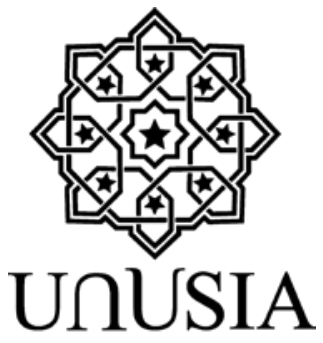

EDITORIAL JOURNAL

Gedung Kampus UNUSIA Lantai 2

Jl. Taman Amir Hamzah No. 5 Jakarta Pusat 10430

E-mail : Islamnusantarajournal@unusia.ac.id or Journalofislamnusantara@gmail.com

Website : http://journal.unusia.ac.id/index.php/ ISLAMNUSANTARA/about 


\section{Table of Contents}

\section{Articles}

1 Ahmad Suaedy

Pengantar Nomor Perdana - Nahdlatul Islam Nusantara

13 Okamoto Masaaki

Anatomy of the Islam Nusantara Program and the

Necessity for a "Critical" Islam Nusantara Study

41 Mohamad Shohibuddin

Artikulasi Islam Nusantara dalam Perjuangan Agraria

89 Ngatawi El-Zastrouw

Menuju Sosiologi Nusantara: Analisa Sosiologis Ajaran

Ki Ageng Suryomentaram dan Amanat Galunggung

145 Amin Mudzakkir

Traditional Islam and Global Religious Connectivity:

Nahdlatul Ulama in The Netherlands

163 Syamsul Hadi

Lasem: Harmoni dan Kontestasi Masyarakat Bineka

209 Muhamad Bindaniji

Traces of Māturīdīsm in the 'Ulamā's Works in Nusantara in the Seventeenth Until Nineteenth Centuries

Book Review

239 Idris Masudi

Islam Dibawa Masuk oleh Orang Nusantara: Dari Data Terserak Buzurgh Al-Ramahurmuzi, 'Ajaibul Hind: Kisah-Kisah Ajaib di Daratan dan Lautan Hindi 
Amin Mudzakkir

Traditional Islam and Global

Religious Connectivity:

Nahdlatul Ulama in The

Netherlands

LIPI (Indonesian Institute of Sciences)

amin.mudzakkir@gmail.com

Abstract: This article examines the Nahdlatul Ulama in the Netherlands. Nahdlatul Ulama is the largest Muslim organization in Indonesia which is now starting to open branches overseas, including in the Netherlands. Despite its traditional pattern, NU has a religious vision which has been very responsive to global connectivity from the beginning. Based on interviews and observations, this article demonstrates the ability of the Dutch NU to portray itself as a religious diaspora organization that bridges the identity needs of its members regarding the homeland and the reality of daily life in the Dutch multicultural society.

Keywords: Nahdlatul Ulama, traditional Islam, religious connectivity, Indonesia, Dutch multicultural society 
Abstrak: Artikel ini membahas Nahdlatul Ulama di Belanda. Nahdlatul Ulama adalah organisasi muslim terbesar di Indonesia yang kini mulai membuka cabang di luar negeri, termasuk di Belanda. NU memiliki visi religius yang sejak awal sangat responsif terhadap konektivitas global. Berdasarkan wawancara dan observasi, artikel ini menunjukkan kemampuan NU Belanda untuk menampilkan diri sebagai organisasi diaspora religius yang menjembatani kebutuhan identitas anggotanya mengenai tanah air dan realitas kehidupan sehari-hari dalam masyarakat multikultural Belanda.

Kata kunci: Nahdlatul Ulama, Islam Tradisional, Indonesia, Masyarakat Multikultural Belanda

الملخص: هذا البحث سيسلط الضوء على جمعية نهية العلماء فرع خاص في

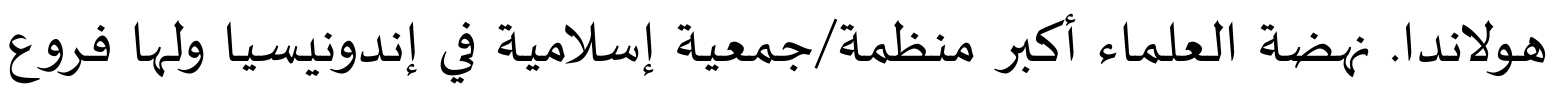
كثيرة منتشرة خارج الوطن الأم الإندونيسي، و منها في هولندا. و نضضة العلماء

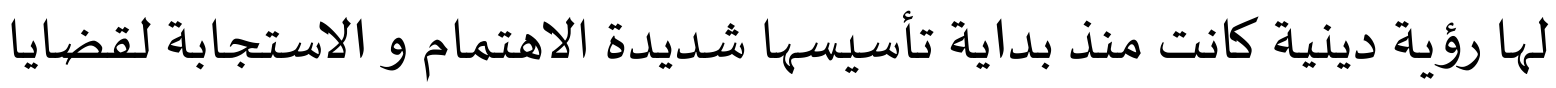



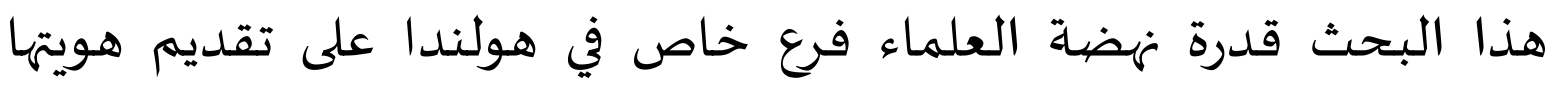

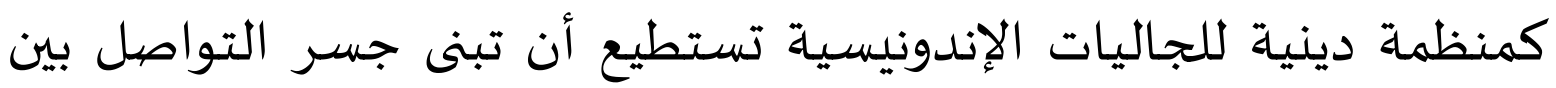

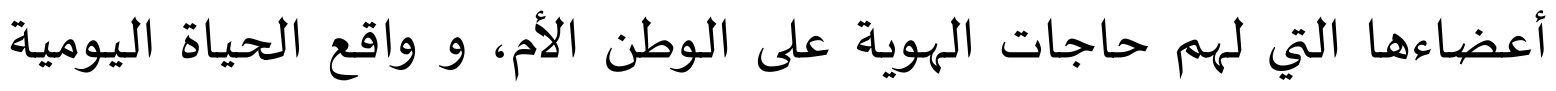

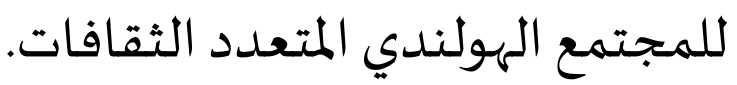

الكلمات الإرشادية: هضية العلماء، الإسلام التقليدي، التواصل الديني،

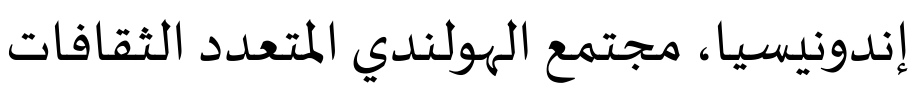




\section{Introduction}

7 he establishment of the Nahdlatul Ulama (NU) branch in the Netherlands, which was officially called the Official Branch of

1 the Dutch NU (PCINU), in 2015 was interesting to study. Born in response to both the situation in Indonesia and in the Netherlands itself, this stance shows efforts to strengthen the significance of NU in the arena of global connectivity. Although it has been known as a traditional Islamic organization that is more locally-oriented, NU was born initially as a response to international events. The demolition of holy sites in the Arabian Peninsula in the early 1920s along with the reign of the Wahabistyle Saudi regime provoked a strong reaction from the pesantren "kyai" in Indonesia, especially Java. They, the pesantren clerics, then established the Hijaz Committee in 1924 which became the forerunner to the establishment of NU in 1926. Thus, the establishment of NU branches in the Netherlands and other countries could be read as an attempt to bring NU back into the arena of connectivity the real global religion was the reason for its existence from the beginning.

Reading of NU's position in the arena of global religious connectivity is often overlooked because of its designation as a traditional Islamic organization. The term derived from academic categorization, such as the work of Deliar Noer (1980), influenced the impression that NU was only involved in local affairs. Not only local, various literature on NU create a frame as if this organization only deals with politics. NU's position and role amid intellectual currents were forgotten. However, now this impression is starting to reverse. While strengthening the symptoms of religious conservatism, both at the local, national, and global levels, NU 
is considered as a source or religious authority that offers alternatives. The establishment of a PCINU abroad adds weight to this assessment.

Nevertheless, the social, religious and political dynamics in the country still strongly influenced the orientation of the Dutch PCINU. Therefore, it would be interesting to see this phenomenon from the perspectives developed in the study of the diaspora. It can be said that they practice what Bennedict Anderson (1992) called the phenomenon of "longdistance nationalism". The point of concern for long-distance nationalists is the conditions in the homeland left behind, not in the place where they live now. However, Anderson's perspective feels inadequate when looking at the work of the Dutch PCINU who also have excellent attention to the conditions in which they are now. Among these is the response to Islamophobia. They actively introduced an Islamic model that was far from the impression of the bearers of Islamophobia to the Dutch public. Therefore, they undoubtedly supported the integration policy undertaken by the Dutch government, especially among immigrants from Muslim countries.

This article will be structured as follows. After the introduction, the next section discusses the origins of PCINU of the Netherlands. Here will be discussed mainly genealogical organizations before. Next is a discussion of the Dutch PCINU membership which is increasingly widespread. Later the workers joined in their religious activities. Next is a review of traditional Islamic practices in daily activities, such as recitation, as well as more academic seminars. Finally, there is a closing that contains a more abstract review of the main issues and recommendations for further studies.

\section{Origins}

The PCINU Netherlands will never exist if no Indonesian students are studying there. They are the initiators and then become the core administrators who run the wheels of the day-to-day organization. 
Generally, they are postgraduate students who, when in Indonesia, had been involved in NU activities. At least almost all of them are from NU's family background. They want the religious traditions practised in their homeland to be maintained, if possible, to be better developed in overseas lands.

However, the establishment of the PCINU of the Netherlands came from a long historical process. Aspirations for caring for religious traditions brought from the homeland had emerged since 1971 when several Indonesian youths founded the European Muslim Youth Association (PPME) (Sujadi, 2017). These young men are former Indonesian students in the Middle East. During their college holidays, they used to look for work in European countries, including the Netherlands. Then some of them even decided to stay there after finishing college. PPME develops not only in the Netherlands, but also in Germany, although PPME in the Netherlands remains the largest. Until now PPME still exists, especially in large Dutch cities, such as in Amsterdam, The Hague and Rotterdam.

Among the prominent PPME founders was Abdurrahman Wahid who would later become the leader of NU and the 4th President of the Republic of Indonesia. After studying in Baghdad, he tried to continue his studies in Europe, but in fact, his diploma had to be equalized first. While preparing everything, Wahid lived in the Netherlands. Because his activist character had been built a long time ago, together with his colleagues, he founded PPME as a gathering event. However, at that time, establishing compulsory worship was not easy because the Muslim population was indeed tiny. Initially, Wahid even wanted to be made Chairman, but apparently, his family in Jombang asked him to go home to lead a school in Tebuireng.

The religious practices developed by PPME are quite diverse, reflecting the diversity of religious orientations in the country. Some of the management and members have traditional Islamic backgrounds, while 
others are modernist Islamists. Nevertheless, at that time, the dichotomy of traditionalist versus modernist Islam did not cause a severe struggle for discourse. Their focus was on how to make Muslims, especially those from or associated with Indonesia, be able to worship in secular Europe properly. Even if there are internal disputes, it is more organizational.

However, since the 2000s, there have been significant changes. Since then, the identity debate among Muslims has intensified. Differences in religious views are sharpened, especially between Nahdliyyin and Salafi groups. Following the global Salafi renaissance that began in the 1970s, Salafi activists in the Netherlands have become more open about their ideological points, namely the purification of Islamic teachings from all things deemed unwarranted in the Koran and its guidance in As-Sunnah. What is meant by Salafis here is the Wahabis who are based in Arabia. In the context of the Indonesian Muslim community in the Netherlands, they are mostly Arab descendants from Surabaya or Malang. Most are based in Amsterdam. Therefore, the locus of contention is PPME Amsterdam. Salafi-based PPME members criticized the custom of the "tahlilan" and 'maulud' rituals that are usually performed by PPME mosques. However, not only criticized, they asked that the activity no longer be carried out at the mosque. Tensions escalated in 2005 when a Salafi group succeeded in taking over the management of the mosque, thus leaving the NU members of the PPME. The first group no longer uses the name PPME, but EuroMuslim, because the name PPME is carried by the second group who then must find a new mosque.

Since the PPME Amsterdam split, the awareness to form an organization that accommodates explicitly traditionalist Muslim religious aspirations has strengthened. Communication with the Central Board of Nahdlatul Ulama (PBNU) in Jakarta began to be built. However, at that time, the PBNU itself did not yet have an institutional framework to respond. The next step was to establish the Nahdlatul Ulama Student Family (KMNU) in 2009. As the name suggests, its members are students. They do activities, 
especially when there are Islamic holiday celebrations, such as "mauludan' or "rajaban". At the same time, communication was continued with PBNU in Jakarta to establish overseas NU branches. Finally, the official decree on the establishment of the PCINU of the Netherlands came out in 2013, signed by the PBNU General Chairperson, KH Said Aiql Siradj. Initially, he would appoint his management, but it did not happen. The inauguration was only successfully carried out in 2015 when KH Musthafa Bisri, who served as one of PBNU's Syuriyah leader, visited the Netherlands.

In its development, the Dutch PCINU has experienced three changes in the management of 'tanfidziyah' (executive). The first period (20152017) was chaired by Fachrizal Affandi (Leiden) and secretary Adieyatna Fajri (Leiden). Next, the second period (2017-2019) was chaired by Ibnu Fikri (Amsterdam) and secretary Fahrizal Yusuf Affandy (Wageningen). Also, the third period (2019-2021) was chaired by Muhammad Latif Fauzi (Leiden) and secretary Fahrizal Yusuf Affandi (Wageningen). All of them were postgraduate students, and this is the problem, their stay in the Netherlands is limited, a maximum of 5 years. Until now, it is still difficult to find members who want to be responsible for being administrators outside of students (Correspondence, M. Latif Fauzi, Thursday, October 31 2019).

What is interesting is the leadership of 'syuriah'. Since its establishment until now the position of 'rais syuriah' which means KH Nur Hasyim Sobandi holds the highest leader[A8]. Hasyim does have a unique position. His daily work is the local staff of the Indonesian Embassy in The Hague. He is not a diplomat. As such, he did not experience staff rotation as diplomats did. This condition is considered beneficial for the stability and sustainability of the Dutch NU. His background as a 'santri', even having studied at Al-Azhar University, Egypt, enabled him to occupy the role and function of managing religious activities at the Indonesian Embassy. Now he is appointed as Chairman of the Al-Hikmah Mosque Foundation which indirectly belongs to the Indonesian Embassy after the 
Probosutedjo family claimed they could no longer manage it themselves. With these various positions, NU has the opportunity to take advantage of broad access to many things, especially to the Al-Hikmah Mosque which has an essential role in the Indonesian Muslim community in the Netherlands (Interview with Nur Hasyim Sobandi, March 12 2019)

Meanwhile, NU elder who is also one of the founders of PPME is $\mathrm{KH}$ Ahmad Hambali Maksum. In the organizational structure of the PCINU of the Netherlands, Hambali held the position of "mustasyar" (advisor). Originally from Purwokerto, Hambali was a close friend of Abdurrahman Wahid while studying in Baghdad. The two then together went to Europe. When Wahid returned to Indonesia, Hambali lived and worked in an insurance company in the Netherlands. Now he is retired. From the beginning, on the sidelines of the busywork, he actively guides people who want to learn Islam. Hambali asserted that the establishment of the PCINU was a mere institutionalization of the aspirations of traditionalist Muslims who were initiated in PPME. However, because the composition of PPME members was considered too diverse, including Dutch converts to Islam (converts), the Dutch PCINU was established to be more focused (Interview, Ahmad Hambali Maksum, March 9 2019)

\section{Expanding Membership}

In its development, the establishment of PCINU received a very positive response from various groups, not only students. Apart from the local 'mukimin' who had been active previously in PPME, the group that was enthusiastic about PCINU was the workers. They are now actively organizing themselves correctly, then hold regular activities at the AlHikmah Mosque, The Hague. Not only religious recitation, as usual, they are also quite diligent in holding joint art exercises, such as 'hadrah' and flare. Since 2016 they officially named their group as Tombo Ati.

The name Tombo Ati comes from a WhatsApp group created in 2014. Members of the group are Indonesian workers who live around the Hague 
who have long had regular recitation sessions every Friday the first week and Sunday the third week at the Al-Hikmah Mosque. Initially not named, just recitation, but since 2016 they use the name of the WhatsApp group as the name of the recitation group. However, now the recitation time is no longer Friday, but once every two weeks Sunday. The reason is to be more practical. If the time is Friday and Sunday, many people forget, whereas initially Friday was provided for those who work on Sunday.

The prime mover of the Tombo Ati group is Nana Supriatna. This man who was born in Cirebon had worked in Bandung and then sought work fortune in the Netherlands since 2014. His status was without paperwork. Nevertheless, Nana has a full circle of relationships. Since arriving in the Netherlands, he immediately joined activities at the Al-Hikmah mosque. Because he had studied at a pesantren, he was asked for his help to take care of the mosque, including leading congregational prayers and teaching reading the Qur'an. In the Netherlands, it must be admitted, looking for people who have sufficient religious knowledge and are willing to work voluntarily in the mosque is very difficult. When Tombo Ati was finally inaugurated, Nana was entrusted with coordinating the group, including communicating with PCINU administrators (Interview, Nana Supriatna, March 14, 2019).

The focus of the recitation of Tombo Ati is fiqh. More specifically, the fiqh taught was the Syafii school of figh as taught at NU pesantren in Indonesia. The books used as references are the same, such as Safinatun Naja, Kifayatul Awam, to Fathul Mu'in. The discussion starts with basic lessons, such as purification or "thaharah". It turns out that it is needed by the members of the recitation group who are generally laymen. Now and then taught other things that are "fardu kifayah" (collective obligation), such as "caring the corpse"; ranging from bathing, putting on kafan/ white piece of cloth to the body, ("Mengkafani"), "to pray for the corpse ("menshalatkan") and memakamkan ("to bury"). 
The study of Tombo Ati has a permanent teacher, namely KH Nur Hasyim Sobandi who also, as already mentioned, is Rais Syuriyah of the Dutch PCINU. However, if there are guests from Indonesia who are considered to have adequate knowledge qualifications, Hasyim himself usually likes to ask the person concerned to fill the event. In March 2019 yesterday, for example, the Tombo Ati study was filled by a lecture by Dr Faqihuddin Abdul Kodir from Cirebon. He introduced his book "Qira’ah Mubadalah: Progressive Interpretation of Gender Justice in Islam". I attended the event. The audience was very enthusiastic about the theme. There is a woman, for example, asking how fiqh views long-distance relationship marriages, an actual issue for those who are separated from their partners because they have to work in the Netherlands. Faqihuddin explained in detail, including how the law of phone sex for husband and wife.

In carrying out its activities, Tombo Ati has a self-supporting budget and financial management. The permanent members totalling 25 people are obliged to submit a Regular Sodaqah Every Month of 7.5 euros. In every recitation held every two weeks on Sunday afternoons, the charity box provided usually receives up to 100 euros. By way of collecting money like that, Tombo Ati can employ "marbots" to clean and tidy up the AlHikmah mosque ahead of Friday prayers. They are paid 20 euro. "Tombo Ati” even donates mosque finances to nearly 200 euros each month.

As already mentioned, members of Tombo Ati are mostly undocumented workers. Generally working in the domestic sector, a kind of cleaning maid, sometimes cooking also depends on the request of the employer, or caregivers of parents. Some of them are members of the Indonesian Migrant Worker Union (IMWU). Nana Supriatna is the Head of the IMWU Den Haag. In addition to the mosque, Nana was actively organizing the rights of her fellow workers, especially those without documents. In the Netherlands, although illegal, they have certain rights as workers. These rights are highly respected, including by the users of 
their services, the Dutch people. Nana's dualistic position is very strategic. In the mosque, members of Tombo Ati also talk to each other about work, so that through this a cultural mechanism is created to protect each other, especially considering their immigration status which is full of risks.

Besides recitation, the exciting thing from Tombo Ati is art activities. They have an art group called Nur Hollandi. After the routine recitation, they will usually put out musical instruments flying, then together sing the songs of blessings or other praise. Sometimes also Javanese songs because most of them are Javanese. Some of them uploaded to YouTube. If requested by PCINU, they also escort Islamic art groups invited from the country. Several times, for example, they helped show the group Ki Ageng Ganjur led by Sastro Ngatawi in the Netherlands. The group itself was asked to perform at the Al-Hikmah Mosque. Its members also interpret more than just channelling a hobby, Tombo Ati's art activities as da'wah. They want to challenge the impression that is often understood by the Dutch about Islam as if Islam is a religion of war. Tombo Ati tried to show that Islam is a religion of peace that significantly appreciates art.

\section{Defending Tradition}

NU was established to defend an Islamic tradition of "Sunnah Wal Jamaah" experts from attacks by other Islamic groups, especially those who are ideologically linked with Wahhabism and Salafism. The tension between NU and Wahhabism-affiliated groups occurred not only in the Netherlands today but also in his birthplace in Indonesia from the beginning. In several academic works, this situation is described as a dichotomy between traditionalist Islam versus modernist Islam. If the reference is to the form of organization, the description is accurate. Nevertheless, if what is meant is something more substantial, related to the basis of thought or belief, then that can be misleading. NU, called traditionalist Islam, is considered more compatible with "modernity" (if what is meant by modernity is its aspect of thought, not technique) 
than modernist Islamic groups. However, it must be recognized from the organizational side that $\mathrm{NU}$ was very traditionalist.

However, this article still uses the traditional Islamic term as a category attached to NU's religious vision. This term refers to attitudes towards the great intellectual and spiritual traditions of Islam. So far, NU has succeeded in showing itself as an organization that is very concerned with "sanad" or genealogy in the Islamic realm. Practically this is demonstrated by the use of yellow books that mu'tabar (authoritative) as a reference in explaining various religious issues. Even in the Netherlands, the books are still used routinely in recitation activities. Besides, spiritually, NU stressed the importance of a "wasilah" (affinity) that was read in "tahlilan", "istigotsah", and other practices of prayer. The area was connected to the clerics closest to his lifetime to the Prophet Muhammad. In every Dutch PCINU activity, the "tawashul" series always opens the program, reminding the audience of the long chain of religious traditions in a trusted line.

Traditional Islam a la NU originates from the doctrine of the expert Sunnah Wal Jamaah. At the level of faith, it refers to Al-Ashari and AlMaturidi. Further, at the fiqh level, the traditionalists NU refers to Hanafi, Maliki, Shafi'i, and Hambali. Also, at the level of Sufism, they took "sanad" to Al-Ghazali and Junaid Al-Baghdadi. These subjects continue to be taught to the worshipers of the Dutch PCINU recitation. In Nur Hasyim's confession, many of those present had just heard the points for the first time. During this time they practice, but do not know what the reference. Although the rituals of worship that carried out by the Nahdliyyin residents were accused as heretics thus had to be abandoned, these critical points were expressed.

To ensure that religious issues were conveyed, at a particular moment, the PCINU invited teachers from Indonesia or Middle Eastern countries. Certain moments are, for example, the month of Ramadan. During the month of Ramadan, twice in a row, PCINU invited a cleric from Indonesia 
through connections Nur Hasyim Sobandi and Nusron Wahid, Head of BNP2TKI in Jakarta. They both come from the Holy. Apart from Indonesia, PCINU also invited several Indonesian students who were studying in Morocco (PCINU Morocco). To understanding the worshipers, such invitations were addressed to connect PCINU with fellow Nahdliyyin both in Indonesia and elsewhere.

The PCINU's activity at the Al-Hikmah Mosque attracted the attention of the surrounding community. In contrast to other mosques in the Netherlands which generally separate prayer places for men and women, the Al-Hikmah Mosque places the prayers in one room, both during praying time and recitation. On the lower floor of Al-Hikmah, men and women join without a partition. For local communities, especially around the township of Moerwijk, this phenomenon is considered progress because it breaks the impression of Islamophobics who say Islam is segregative towards women. Therefore, the local municipal government has repeatedly invited mosque managers to take part in multicultural festival activities. They even promoted the Al-Hikmah model to other Muslim groups as an ideal of integration in the Netherlands. Meanwhile, the Moroccan migrant group that dominates the region also respects, even some people who are considered pious from among them often act as priest prayers in congregation.

Because students front it, the academic style is very much colouring the activities of the Dutch PCINU. Among the most monumental was the holding of two international seminars with the theme "Islamic Nusantara". The first seminar was held at Vrije Universiteit, Amsterdam, March 27 2017, with the theme "Rethinking Indonesia's Islamic Archipelago: From Local Relevance to Global Significance". In addition to the speakers who came from various countries, especially from Indonesia itself, this event was attended by 5 Indonesian ambassadors who were serving in the Netherlands, Lebanon, Saudi Arabia, Algeria, and Azerbaijan. 
Meanwhile, the second seminar was held at Radboud University Nijmegen, 12-21 June 2019, with the theme "Seeking the Middle Path (Al-Wasatiyya): Articulations of Moderate Islam". Attended by religious minister Lukman Hakim Saefuddin, this event also brought speakers from various countries. Katib Aam Syuriyah PBNU KH Yahya Staquf closed the program while giving a lecture on religious moderation and what $\mathrm{NU}$ had done in this regard. The Dutch public is enthusiastic about this event, As revealed by the Executive Director of Radboud University, Nijmegen, Daniel Wigboldus.

\section{Closing Remarks}

Based on the description above, can we call the existence of the Dutch PCINU a diaspora phenomenon? According to Helly (2000), there are four characteristics of the diaspora, namely (1) the consciousness of a destiny of social precarity, of fate always uncertain and sometimes dangerous, which past traumatic events, such as dispersion, symbolize; (2) the legacy of this consciousness through narrations and the construction of collective memory, sometimes reinvented by elites (schools, newspapers, associations, religious institutions and others); (3) multiple seats of establishment and cultural expression; and (4) economic and cultural means to maintain a multinational network between those seats". Especially the second and third points, the concept of the diaspora can be applied to the experience of the Dutch PCINU. However, what was done by them was an attempt to maintain the traditional Islamic religious narration of the Sunnah WalJamaah an-anhdliyyah experts in the overseas something with what they understood before in their homeland. The effort is carried out in such a way as to form a global traditional Islamic religious connection in increasingly stringent identity identities.

For the government, both Indonesia and the Netherlands, the religious practices carried out and disseminated by PCINU are an example of the development of a pluralist society. The Indonesian government, through 
the Indonesian Embassy in The Hague, is therefore very supportive of their activities. The Dutch government follows the same attitude. As mentioned above, the Moerwijk municipal government has repeatedly invited the managers of the Al-Hikmah Mosque, which is also a PCINU to be seen in local multicultural festival activities. They appreciated the models of religious formation a la NU that gave a new nuance amid the strengthening sentiment of religious conservatism on one side and Islamophobia on the other.

Finally, the experience of the Dutch PCINU is fertile ground for diaspora studies, especially in terms of religion. Indeed, if look at history, this is not something new. Azyumardi Azra (1994) for example shows the vital role of Indonesian scholars in global religious connectivity in the 17th and 18th centuries, as well as Laffan (2003) for the period of the 19th and 20th centuries. However, these studies look more at outside influences, especially from Arabic to Indonesia, not vice versa. Knowledge about how Indonesian communities abroad maintain their religious commitments, as well as their contribution to socio-cultural problems in their homeland, is still lacking. This fact is an opportunity and a challenge for future diaspora studies. [] 


\section{Bibliography}

Anderson, Bennedict R. O'G. 1992. "Long-distance nationalism: World capitalism and the rise of identity politics". The Wertheim Lecture 1992. CASA-Centre for Asian Studies Amsterdam.

Azra, Azyumardi. 1994. Jaringan ulama: Timur Tengah dan kepulauan Nusantara abad XVII dan XVIII : melacak akar-akar pembaruan pemikiran Islam di Indonesia. Bandung: Mizan.

Helly, Denise. 2006. "Diaspora: History of an idea" dalam Haideh Moghissi (ed.). Muslim diaspora: Gender, culture and identity. London/New York: Routledge.

Laffan, Michael Francis. 2003. Islamic nationhood and colonial Indonesia: The umma below the winds. London/New York: Routledge.

Noer, Deliar. 1980. Gerakan Moderen Islam di Indonesia, 1900-1942. Jakarta: LP3ES.

Sujadi. 2017. Persatuan Pemuda Muslim se-Eropa: identity, encouragement for giving, and network, 1971-2009, Disertasi Universitas Leiden.

Wawancara, Ahmad Maksum Hambali, 9 Maret 2019.

Wawancara, Nur Hasyim Sobandi, 12 Maret 2019.

Wawancara, Nana Supriatna, 14 Maret 2019.

Korespondensi, M. Latif Fauzi, 31 Oktober 2019.

https://www.nu.or.id/post/read/107683/konferensi-internasional-nu- 
belanda-perkuat-promosi-islam-moderat

http://nubelanda.nl/conference2019/selected-papers/120conference2019

https://islam.nu.or.id/post/read/76456/seminar-internasional-islamnusantara-awali-konfercab-nu-belanda 



\section{Author Guideline}

SLAM NUSANTARA: Journal for Study of History and Culture
is a multidisciplinary journal for scholars who have a concern about
Islamic studies and Indonesia studies focusing on education, thoughts, philosophy, history, law, politics, economy, anthropology and sociology.

ISLAM NUSANTARA: Journal for Study of History and Culture is a peer-reviewed journal that is published twice a year in June and December by Faculty of Islam Nusantara University of Nahdlatul Ulama Indonesia (UNUSIA) Jakarta.

Papers submitted for publication must conform to the following guidelines:

1. Papers must be typed in one-half spaced on A4-paper size;

2. Papers' length is about $6,000-10,000$ words;

3. All submission must include a 200-300 word abstract;

4. Full name(s) of the author(s) must be stated, along with his/her/ 
their institution and complete e-mail address;

5. All submission should be in OpenOffice, Microsoft Word, RTF, or WordPerfect document file format;

6. Arabic words should be transliterated according to the style of 'Islam Nusantarad Studies';

7. Bibliographical reference must be noted in footnote and bibliography according to 'Islam Nusantarad Studies' style.

\section{Examples of footnote style:}

${ }^{1}$ Ryan Sugiarto, Psikologi Raos: Saintifikasi Kawruh Jiwa Ki Ageng Suryomentaram, (Yogyakarta: Pustaka Ifada, 2015), p. 139.

${ }^{2}$ Nur Syam, Tarekat Petani: Fenomena Tarekat Syattariyah Lokal, (Yogyakarta: LkiS, 2013), h. 164.

${ }^{3}$ Syam, Tarekat Petani, p. 173.

${ }^{4}$ Ubaidillah Achmad dan Yuliyatun Tajuddin, Suluk Kiai Cebolek Dalam Konflik Keberagamaan dan Kearifan Lokal, (Jakarta: Prenada, 2014), p. 140.

${ }^{5}$ Nur Syam, Tarekat Petani, p. 99.

${ }^{6} \mathrm{M}$. Quraish Shihab, Tafsir Al-Misbah, vol. 14 (Bandung: Lentera Hati, 2013), p. 167.

${ }^{7}$ Deny Hamdani, "Cultural System of Cirebonese People: Tradition of Maulidan in the Kanoman Kraton," Indonesian Journal of Social Sciences 4, no. 1 (January-June 2012): p.12.

${ }^{8}$ Hamdani, “Cultural System of Cirebonese People," p. 14.

${ }^{9}$ Deny Hamdani, "Raison de'etre of Islam Nusantara," The Jakarta Post, 06 Agustus 2015, p. 5. 
${ }^{10}$ Azyumardi Azra, "Islam di "Negeri Bawah Angin" dalam Masa Perdagangan," Studia Islamika 3, no. 2 (1996): h. 191-221, review buku Anthony Reid, Southeast Asia in the Age of Commerce (New Haven: Yale University Press, 1988).

\section{Example of Bibliography}

Bizawie, Zainul Milal. Masterpiece Islam Nusantara: Sanad dan Jejaring Ulama-Santri (1830-1945). Tangerang: Pustaka Compass, 2016).

Madjid, M. Dien dan Wahyudi, Johan. Ilmu Sejarah: Sebuah Pengantar. Jakarta: Prenada Media Group, 2014.

Banawiratma, JB. dkk., Dialog Antarumat Beragama: Gagasan dan Praktik di Indonesia. Bandung: Mizan Media Utama, 2010.

Sejarah Melayu/Malay Annals. Kuala Lumpur, Oxford University Press, 1970.

Tim Forza Pesantren. Ijtihad Politik Islam Nusantara:Membumikan Fiqih Siyasah Melalui Pendekatan Maqasid asy-Syariah. Kediri, Lirboyo Press, 2015.

Mastuki dan El-Saha, M. Ishom, ed. Intelektualisme Pesantren:Potret Tokoh dan Cakrawala Pemikiran di Era Pertumbuhan Pesantren. Jakarta: Diva Pustaka, 2003.

Suriasumantri, Jujun S. Ilmu Dalam Perspektif: Sebuah Kumpulan Karangan Tentang Hakekat Ilmu, Cet. XII. Jakarta: Yayasan Pustaka Obor Indonesia, 2012.

Simuh. Sufisme Jawa : transformasi tasawuf Islam ke mistik Jawa. Yogyakarta: Yayasan Bentang Budaya, 1995. Reprint, Yogyakarta: Narasi, 2016. 
Muhajir, Afifuddin, "Islam Nusantara untuk Peradaban Indonesia dan Dunia." Dalam Akhmad Sahal dan Munawir Aziz, ed. Islam Nusantara: Dari Ushul Fiqh Hingga Konsep Historis. Bandung: Mizan Pustaka, 2015.

Islam, Adib Misbahul. "Nazam Tarekat: Perlawanan Kiai Ahmad arRifa'i terhadap Birokrasi." Dalam Islam Nusantara Past and Present:Proceeding of International Conference on Islam Nusantara (ICON) 2014. Jakarta: Pusmabit, 2014: h. 55-73.

Affan, Heyder. "Polemik di balik istiIah 'Islam Nusantara." Artikel diakses pada 22 Juni 2015 dari http://www.bbc.com/indonesia/berita indonesia/2015/06/150614_indonesia_islam_nusantara

Malikov, Azim. "Islam: Saints and Sacred Geographies." Dalam Suad Joseph, ed. Encyclopedia of Women and Islamic Cultures, vol. V. Leiden: Brill, 2007: h. 223-225.

Hamdani, Deny. "Raison de'etre of Islam Nusantara." The Jakarta Post, 06 Agustus 2015.

"Batunaga, Bagian dari situs lebih luas," Pikiran Rakyat, 16 Mei 2014.

Hamdani, Deny. "Cultural System of Cirebonese People: Tradition of Maulidan in the Kanoman Kraton." Indonesian Journal of Social Sciences 4, no. 1 (January-June 2012): h.12.

Hosen, Nadirsyah. "Islam Nusantara: Islam Lokal yang Menuju Islam Global?” Gatra, 2 Maret 2016, h. 60.

El-Mawa, Mahrus. "Syattariyah wa Muhammadiyah: Suntingan Teks, Terjemahan dan Analisis Karakteristik Syatariyah di Keraton Kaprabonan Cirebon Pada Akhir Abad ke-19." Disertasi S3 Fakultas Ilmu Pengetahuan Budaya, Universitas Indonesia, 2015.

Azra, Azyumardi. "Islam di "Negeri Bawah Angin" dalam Masa 
Perdagangan." Studia Islamika 3, no. 2 (1996): h. 191-221. Review buku Anthony Reid, Southeast Asia in the Age of Commerce. New Haven: Yale University Press, 1988.

Taimiyya, Ibnu. Minhaj as-Sunnah an-Nabawiy. T.tp.: Darul Urubiyya, 1962.

Dawud, Abu. Sunan. Kairo: T.pn., 1951.

Bajuri, Ibrahim. Hasyiah al-Bajuri ala Matn al-Burdah. Bandung: Darul Ma’arif, t.t.

\section{GUIDELINES FOR BOOK REVIEWS}

1. Please include, at the beginning of the review:

Author, Title, Place, Publisher, Date, number of pages, ISBN E.g., Turabian, Kate L. A Manual for Writers of Term Papers, Theses, and Dissertations. Sixth edition. Chicago and London: University of Chicago Press, 1996. $308+$ ix pp. ISBN: 0-226-81627-3.

2. The review should begin with a brief overall description of the book.

3. Matters that may be considered in the body of the review include:

4. The average review should be about 1500 words long. The name, affiliation and email address of the reviewer should appear at the end of the review.

The strengths and weaknesses of the book.

Comments on the author's style and presentation.

Whether or not the author's aims have been met.

Errors (typographical or other) and usefulness of indices.

Who would the book be useful to?

Would you recommend it for purchase?

5. The preferred format for submissions is MS-Word. 


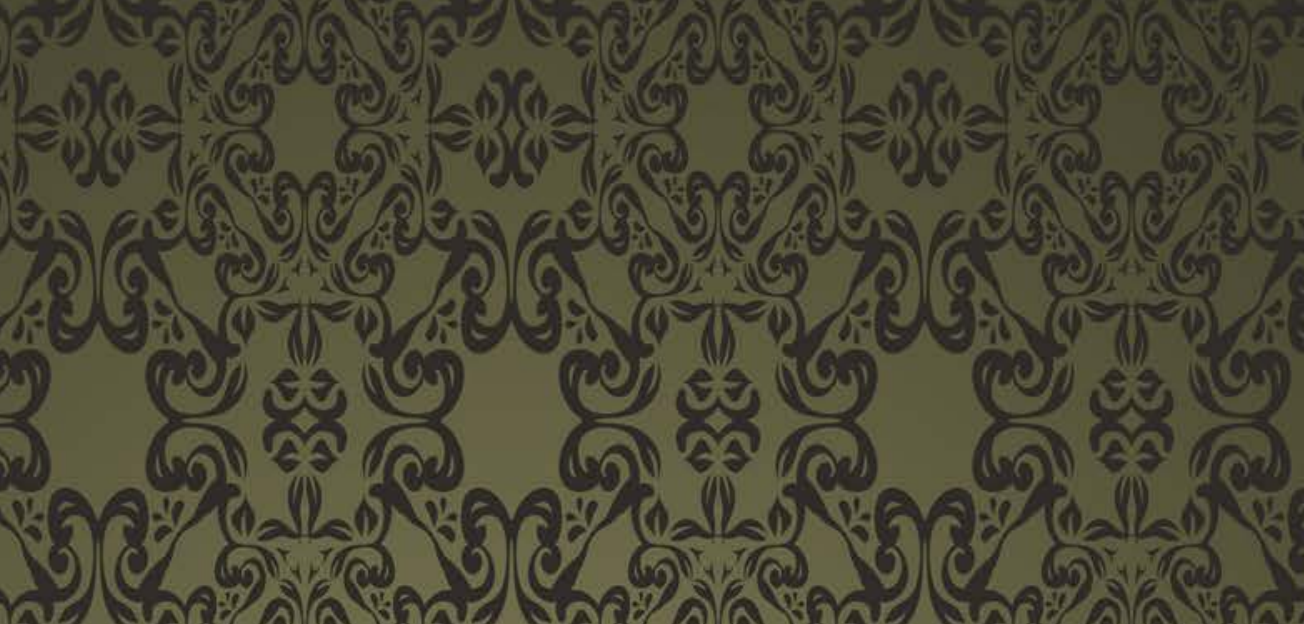

(2.)

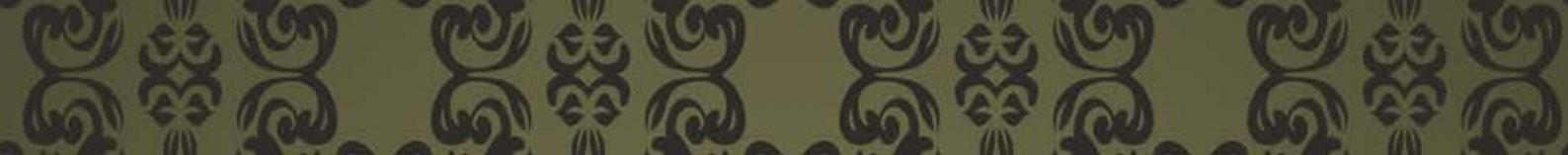





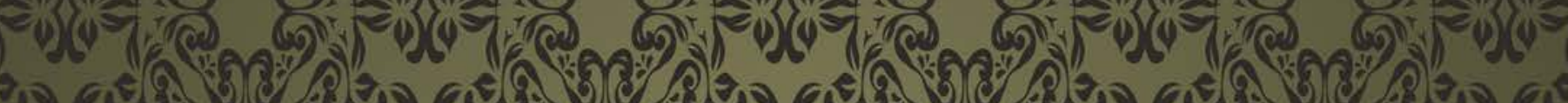

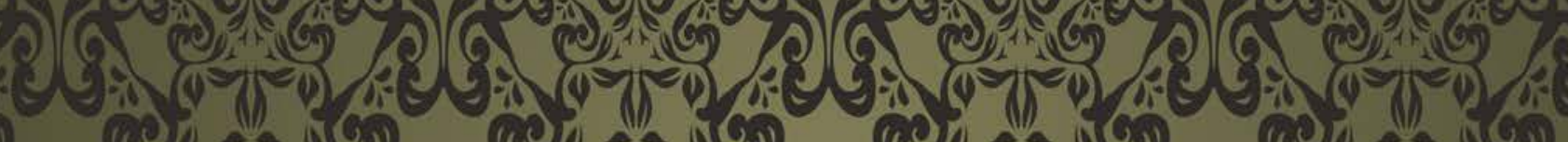

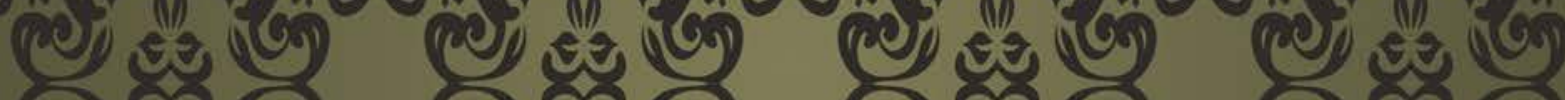

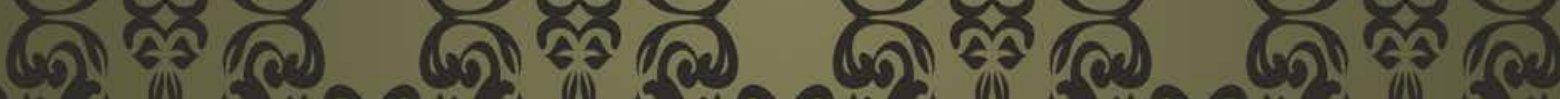
(8):-

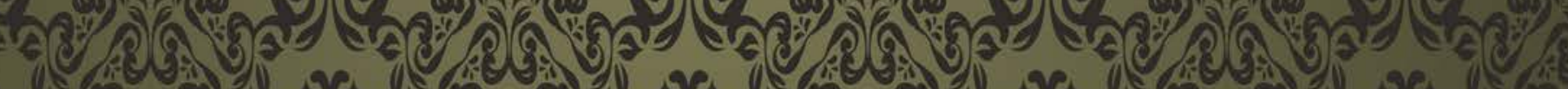

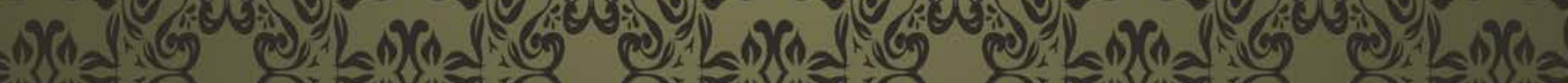

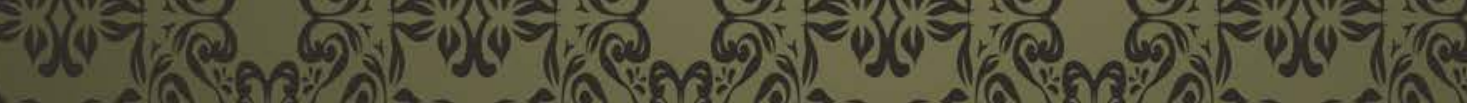
9) (a) (3)

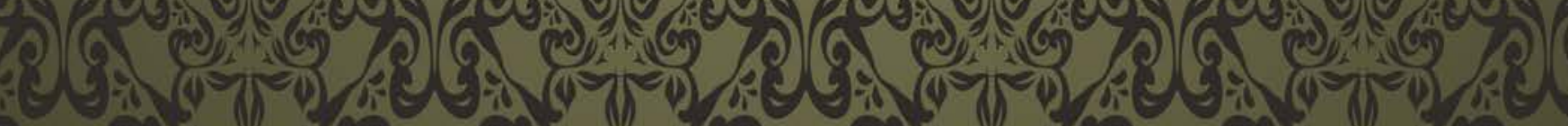

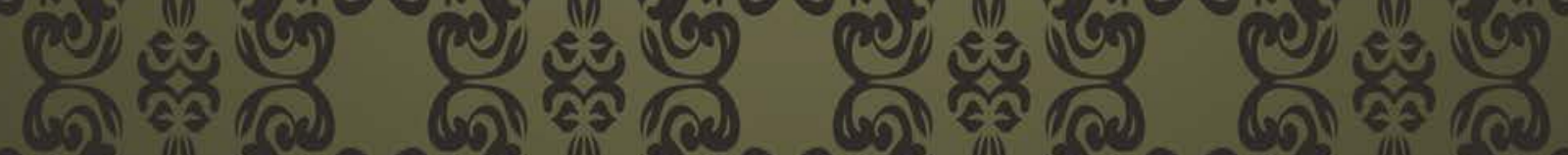

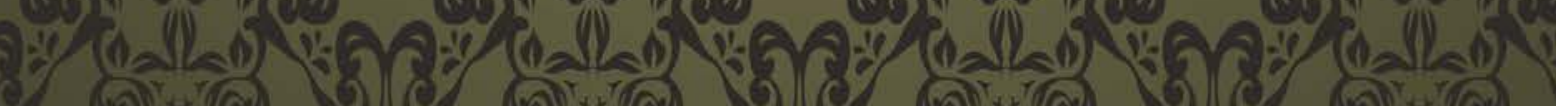

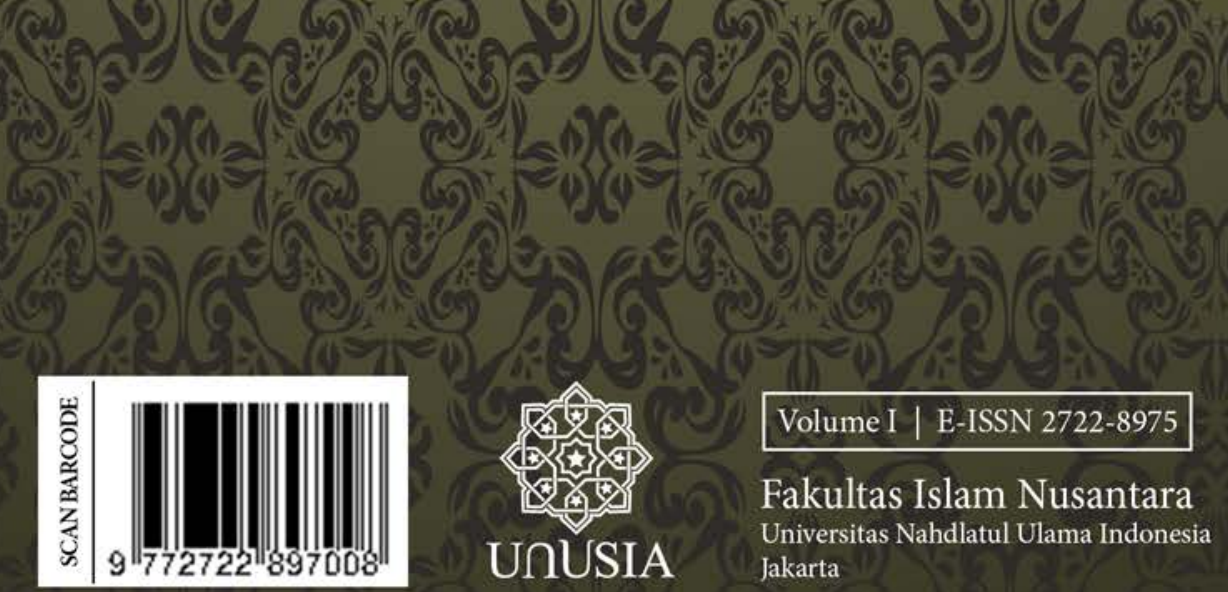

